\title{
Pengaruh Komposisi Media Tanam terhadap Pertumbuhan dan Hasil Bawang Merah
}

\section{Effects of Planting Media Composition on the Growth and Yield of Shallot}

\author{
Sugianto', Kamelia Dwi Jayanti ${ }^{*}$ \\ 1-2Department of Agrotechnology, Faculty of Agriculture, Universitas Sintuwu Maroso, Poso, Sulawesi Tengah, 94612 , Indonesia
}

Received 29 September 2020; Accepted 21 May 2021; Published 30 June 2021

\begin{abstract}
Shallot production in Central Sulawesi recorded a decline from 8.651-8.362 tons, between 2017-2018. However, the use of an accurate composition of the planting medium serves as a possible alternative to boost the yield. Also, the introduction of organic matter tends to increase the nutrient content, influence the aeration, and subsequently leads to drainage. This study is aimed at determining the effect of plant media composition on shallot growth and yield. A randomized block design comprising 4 treatments, termed soil composition, husk charcoal, and goat manure. Each treatment was repeated at 5 times to achieve 20 experimental units. The results showed that the plant media composition indicated a significant effect on the parameters of plant height at age 4 and 6 Weeks After Plantings (WAP), quantities of leaves aged 4 WAP, tillers aged 6 WAP as well as tubers per clump. Similar impacts were also reported on plant height at 2 WAP, the number of leaves aged 2 and 6 WAP, fresh tuber weight, tuber diameter, accumulated weight loss, root length, and available moisture content. Furthermore, the addition of husk charcoal and manure at a volume ratio of soil: husk charcoal: manures $=2: 1: 1$, tends to increase the quantities of leaves, tillers, tubers per clump, as well as plant height, fresh tuber weight, and shallot bulb diameter.
\end{abstract}

Keywords: Goat manure; Rice husk charcoal; Soil moisture; Soil structure

Cite this as (CSE Style): Sugianto, Jayanti KD. 2021. Pengaruh komposisi media tanam terhadap pertumbuhan dan hasil bawang merah. Agrotechnology Res J. 5(1): 38-43. https://dx.doi.org/10.20961/agrotechresj.v5i1.44619.

\section{PENDAHULUAN}

Bawang merah sebagai bumbu penyedap masakan dan obat tradisional sehingga banyak diminati masyarakat. Permintaan bawang merah akan terus meningkat seiring dengan kebutuhan masyarakat yang terus meningkat (Dewi dan Sutrisna 2016). Konsumsi bawang merah dalam rumah tangga selama periode tahun 2002 - 2021 relatif berfluktuasi namun cenderung mengalami peningkatan dari tahun ke tahun. pada tahun 2018 konsumsi bawang merah sekitar 2,764 $\mathrm{kg} / \mathrm{kapita} / \mathrm{tahun}$ atau naik sebesar 7,52 \% dibandingkan tahun sebelumnya (Manurung 2019).

Penanaman bawang merah pada umumnya dilakukan di lahan yang cukup luas, namun untuk skala rumah tangga, budidaya bawang merah dapat dilakukan dalam polybag dengan menggunakan berbagai media tanam yang ada. Media tanam merupakan substansi tempat akar tanaman tumbuh, mengekstrak air dan unsur hara (Landis et al. 2014). Menurut Center for Agriculture Food and the Environment (2020) media tanam harus terdiri dari campuran komponen yang

${ }^{*}$ Corresponding Author:

E-Mail: kamelia_d.jayanti@unsimar.ac.id menyediakan air, udara, unsur hara dan penunjang bagi tanaman.

Budidaya yang dilakukan dalam skala rumah tangga biasanya menggunakan tanah mineral yang berasal dari pekarangan rumah. Tanah mineral yang berasal dari pekarangan rumah pada umumnya kurang subur dan padat sehingga tidak cukup mendukung pertumbuhan dan produktivitas tanaman. Oleh karena itu perlu penambahan bahan organik sebagai salah satu alternatif untuk menciptakan kondisi media tanam yang optimum bagi pertumbuhan dan perkembangan tanaman.

Beberapa bahan organik yang dapat dikombinasikan dengan tanah sebagai media tanam adalah pupuk kandang dan arang sekam padi. Pupuk kandang selain dapat menambah ketersediaan hara pada media tanam, dapat meningkatkan porositas tanah dan kemampuan media tanam menyimpan air. Hasil penelitian Zulkarnain et al. (2013) dan Surya et al. (2017) menunjukkan bahwa aplikasi bahan organik mampu meningkatkan porositas, kandungan C-organik tanah, menurunkan berat isi dan berat jenis, serta meningkatkan kemantapan agregat, porositas tanah dan kadar air pF 4,2.

Sekam bakar dapat digunakan sebagai bahan tanam bawang merah karena memiliki struktur gembur, drainase dan aerasi yang baik sehingga mendukung akar dalam penyerapan unsur hara (Andalasari et al. 2017). Arang sekam padi memiliki sifat porous sehingga 
dapat meloloskan air dengan baik. Arang sekam padi berpengaruh terhadap suhu tanah, kadar lengas tanah dan produksi tomat (Kolo dan Raharjo 2016).

Beberapa penelitian tentang komposisi media tanam telah dilakukan untuk melihat pengaruhnya terhadap pertumbuhan produksi tanaman. Hasil penelitian Juniyati et al. (2016) menunjukkan bahwa komposisi tanah timbunan, arang sekam dan pupuk padat sapi (1:1:3) menghasilkan produksi kangkung darat tertinggi, sedangkan hasil penelitian Syawal et al. (2019) bahwa komposisi media $60 \%$ tanah berbanding $40 \%$ pupuk kandang kotoran sapi berpengaruh nyata terhadap tinggi tanaman, bobot segar dan bobot kering umbi bawang merah.

Jenis dan komposisi bahan organik berpengaruh terhadap pertumbuhan dan produksi tanaman, namun informasi tentang peningkatan proporsi bahan organik pada media tanam yang digunakan khususnya pada budidaya bawang merah dalam polybag masih kurang. Kebaharuan penelitian ini yaitu komposisi tanah dan bahan organik dalam media tanam pada bawang merah dalam polybag. Penelitian bertujuan untuk mengkaji proporsi atau komposisi bahan organik dalam tanah mineral, dan pengaruh terhadap pertumbuhan dan produktivitas bawang merah.

\section{BAHAN DAN METODE}

Penelitian ini dilaksanakan di Desa Betaua, Kecamatan Tojo, Kabupaten Tojo Una-una, Sulawesi Tengah, Indonesia. Bahan yang digunakan antara lain umbi bawang merah varietas Lembang Jumbo, pupuk kandang kambing dan arang sekam padi. Alat yang digunakan antara lain meteran, timbangan digital, cangkul, pisau, ember, polybag, jangka sorong dan alat tulis menulis.

Penelitian ini menggunakan Rancangan Acak Kelompok dengan perlakuan berupa perbandingan komposisi tanah, arang sekam dan pupuk kandang kambing, sebagai berikut:

M1 $=$ tanah $:$ arang sekam $:$ pupuk kandang $1: 1: 1$
M2 $=$ tanah $:$ arang sekam $:$ pupuk kandang 2:1:1
M3 $=$ tanah $:$ arang sekam $:$ pupuk kandang $1: 2: 1$
M4 $=$ tanah $:$ arang sekam $:$ pupuk kandang $1: 1: 2$

Perbandingan yang digunakan dalam menentukan komposisi dalam media tanam adalah perbandingan volume. Perlakukan M1, digunakan 1 ember tanah, ditambah 1 ember arang sekam dan 1 ember pupuk kandang kambing. Ketiga bahan tersebut kemudian dicampur hingga homogen, setelah itu dimasukkan ke dalam polybag. Perlakuan lainnya juga ditakar menggunakan cara yang sama, yaitu menggunakan perbandingan volume.

Tiap percobaan diulang sebanyak 5 kali, sehingga terdapat 20 unit percobaan. Tiap unit percobaan terdiri dari 6 polybag sehingga total polybag yang digunakan adalah 120 polybag. Tiap polybag ditanami satu umbi bawang merah.

Variabel pengamatan meliputi: Tinggi tanaman, jumlah daun, dan jumlah anakan tambahan yang diamati pada umur 2, 4 dan 6 Minggu Setelah Tanam (MST), jumlah umbi per rumpun, bobot umbi segar, diameter umbi, akumulasi susut bobot diamati pada 1,2 dan 3
Minggu Setelah Penyimpanan (MSP), panjang akar dan kadar lengas tersedia media tanam dengan pengambilan sampel media tanam untuk dilakukan pada saat panen, sebelum tanaman dicabut dari polybag. Pengambilan sampel media tanam untuk semua unit percobaan dilakukan pada hari yang sama, yaitu pada pukul 06.00-09.00. Sampel media tanam untuk tiap perlakuan diambil secara acak kemudian dikompositkan.

Kadar lengas tersedia = kadar lengas kapasitas lapangan - kadar lengas titik layu permanen

Kadar lengas kapasitas lapang dan kadar lengas titik layu permanen diukur menggunakan metode Gravimetri dengan rumus sebagai berikut:

$$
\text { kadar lengas }=\frac{(b-a)-(c-a)}{(c-a)} \times 100 \%
$$

dengan $a=$ bobot wadah kosong, $b=$ bobot tanah awal, $\mathrm{C}=$ bobot tanah setelah dioven pada suhu $105^{\circ} \mathrm{C}$ selama 24 jam. Data hasil pengamatan dianalisis menggunakan analisis sidik ragam berdasarkan uji $F$, kemudian dilanjutkan dengan Duncan's Multiple Range Test pada taraf $5 \%$.

\section{HASIL DAN PEMBAHASAN}

Hasil analisis sidik ragam menunjukkan bahwa komposisi media tanam berpengaruh nyata terhadap tinggi tanaman (Tabel 1). Tinggi tanaman tertinggi diperoleh dari media tanam dengan komposisi tanah: arang sekam: pupuk kandang 2:1:1 (Tabel 2). Komposisi 2:1:1 merupakan komposisi paling ideal dan menghasilkan struktur media tanam yang sesuai bagi pertumbuhan bawang merah. Campuran beberapa bahan untuk media tanam harus menghasilkan struktur yang sesuai karena setiap jenis media mempunyai pengaruh yang berbeda bagi tanaman (Syahputra et al. 2014). Selain membentuk struktur tanah yang lebih gembur, pupuk kandang dan arang sekam menyediakan hara yang dapat mendukung pertumbuhan tanaman. Pupuk kandang kambing mengandung hara kalium yang relatif lebih tinggi, namun kadar hara $\mathrm{N}$ dan $\mathrm{P}$ hampir sama dengan pupuk kandang lainnya (Hartatik dan Widowati 2006), sedangkan arang sekam mengandung C sebesar 18,62\%, O sebesar $43,11 \%$ dan Si sebesar 37,43\% (Armynah et al. 2018).

Tabel 1 menunjukkan bahwa komposisi media tanam berpengaruh nyata terhadap jumlah daun. Jumlah daun terbanyak media tanam dengan komposisi tanah : arang sekam : pupuk kandang 2:1:1 dan berbeda nyata dengan perlakuan lainnya. Unsur hara yang diperoleh dari pupuk kandang kambing dan arang sekam dapat mendukung pertumbuhan tanaman. Hasil analisis Sunaryo et al. (2018) menunjukkan bahwa pupuk kandang kambing mengandung $\mathrm{N}$ total $1,15 \pm 0,11 \%, \quad \mathrm{P}_{2} \mathrm{O}_{5}$ total $1,10 \pm 0,14 \%, \quad \mathrm{~K}_{2} \mathrm{O}$ total $2,79 \pm 0,16 \%$, $\mathrm{Ca}$ total $1,56 \pm 0,09 \%$, Mg total $0,42 \pm 0,06 \%$. Arang sekam padi memiliki $\mathrm{pH}$ berkisar 7,23 - 8,38, mengandung $\mathrm{P}$ total $0,95-1,71 \mathrm{~g} \cdot \mathrm{kg}^{-1}, \mathrm{~K}$ total $12,0-20,9 \mathrm{~g} \cdot \mathrm{kg}^{-1}$, Ca total 1,58 - 3,34 g. $\mathrm{kg}^{-1}$, Mg total 0,51 - 1,68 g. $\mathrm{kg}^{-1}$ dan kapasitas tukar kation 3,10 - 7,08 cmol(+). $\mathrm{kg}^{-1} \cdot$ tanah $^{-1}$ (Tsai dan Chang 2020). Selain itu, pemberian bahan organik berupa pupuk organik dan arang sekam dapat menciptakan kondisi aerasi dan drainase yang baik dalam media tanam. Menurut Blok (2017), pada 
umumnya partikel organik memiliki sifat yang berbeda. dengan partikel mineral karena memiliki porositas internal yang mempengaruhi penyimpanan air dan udara.

Komposisi media tanam berpengaruh terhadap jumlah anakan umur 6 MST (Tabel 1). Perlakuan terbaik adalah media tanam dengan komposisi tanah: pupuk kandang: arang sekam sebesar 2:1:1. Hasil serupa dapat dilihat pada penelitian Kurnianingsih et al. (2019) namun dengan penggunaan media tanam tanah dan pupuk kandang ayam dengan perbandingan (3:1) dapat meningkatkan jumlah anakan per rumpun. Penambahan pupuk kandang dan arang sekam selain dapat meningkatkan kesuburan tanah, juga dapat memperbaiki struktur tanah menjadi lebih gembur, sehingga jangkauan akar dalam menyerap hara, air dan udara lebih optimal. Pupuk kandang kambing mengandung $\mathrm{N}$ total $1,15 \pm 0,11 \%, \quad \mathrm{P}_{2} \mathrm{O}_{5}$ total $1,10 \pm 0,14 \%, \quad \mathrm{~K}_{2} \mathrm{O}$ total $2,79 \pm 0,16 \%$, $\mathrm{Ca}$ total $1,56 \pm 0,09 \%$, Mg total 0,42 $\pm 0,06 \%$, S total $2050 \pm 16,09$ ppm (Sunaryo et al. 2018), sedangkan arang sekam padi mengandung mineral Si yang tinggi, $\mathrm{C}, \mathrm{O}$ dan $\mathrm{K}$ serta memiliki porositas makro dengan skala 1-10 $\mu$ (Varela et al. 2013). Sifat fisik tanah yang baik berdampak pada perkembangan akar yang lebih dalam dan luas sehingga daya serap hara dan air yang dibutuhkan tanaman juga semakin baik dan pada akhirnya akan mendukung pertumbuhan tanaman (Kantikowati et al. 2019). Hasil penelitian Ramli et al. (2016) menunjukkan bahwa pemberian pupuk kandang dapat memperbaiki bulk density, agregat tanah, kadar air kapasitas lapang dan porositas tanah. Hasil serupa juga ditunjukkan oleh penelitian Ghorbani et al. (2019) bahwa tanah yang diberikan arang sekam padi mengalami peningkatan kapasitas tukar kation sebesar 19-30\% dan peningkatan porositas sebesar 7,45-33,66\% dibandingkan tanah yang tidak diberi arang sekam padi.

Proporsi arang sekam dan pupuk kandang dalam media tanam berbanding terbalik dengan parameter hasil bawang merah. Jumlah, bobot segar dan diameter umbi bawang merah mengalami penurunan dengan semakin banyaknya proporsi arang sekam maupun pupuk kandang dalam media tanam. Hal ini dikarenakan media tanam yang proporsi arang sekam dan pupuk kandangnya lebih banyak dibandingkan tanah mineral menyerap dan menahan air lebih banyak dari pada yang dibutuhkan tanaman sehingga mengganggu pembentukan umbi bawang merah. Sekam padi memiliki kapasitas menahan air sebesar $251 \%$, namun ketika sekam padi mengalami proses karbonisasi menjadi arang sekam maka kapasitas menahan airnya meningkat menjadi 353\% (Varela et al. 2013), sedangkan penambahan pupuk kandang dalam media tanam meningkatkan kapasitas menahan air dua kali lipat dibandingkan dengan penambahan kompos (Vengadaramana dan Jashothan 2012). Umami et al. (2011), menyatakan bahwa kadar air yang terlalu tinggi dalam tanah dapat menghambat pembentukan umbi, sehingga bobot umbi cenderung rendah. Bawang merah lebih sensitif terhadap tekanan air selama pembentukan dan pembesaran umbi daripada selama tahap vegetatif (Khokhar 2017). Kondisi kelebihan air yang dialami bawang merah dalam jangka waktu yang lama menyebabkan penurunan bobot kering umbi (Sudarma dan Proklamita 2012), namun bobot basah dan bobot kering umbi akan meningkat dengan berkurangnya frekuensi penyiraman (Ariska dan Rachmawati 2017).

Susut bobot umbi disebabkan oleh adanya proses penguapan dan respirasi yang terjadi pada saat umbi disimpan. Tabel 1 menunjukkan bahwa komposisi media tanam berpengaruh sangat nyata terhadap akumulasi susut bobot umbi bawang merah. Akumulasi susut bobot tertinggi untuk semua umur penyimpanan diperoleh dari media tanam dengan komposisi tanah : arang sekam : pupuk kandang 1:1:2 (Tabel 3). Pupuk kandang memiliki kemampuan menyimpan air yang baik, sehingga proporsi pupuk kandang yang lebih banyak dibandingkan bahan mineral menyebabkan kadar air yang tersimpan dalam tanah lebih banyak. Pupuk kandang kambing mengandung bahan organik sebanyak $31 \%$ dengan rasio $\mathrm{C} / \mathrm{N}$ sebesar $20-25 \%$ (Hartatik dan Widowati 2006), KTK 23,942 m.e/100 g (Lumbanraja dan Harahap 2015), bulk density 750 kg m3 , kandungan lengas 58,30\%, kapasitas pegang air 3,00 g air/g sampel kering dan porositas 41,57\% (Khater 2015). Hasil penelitian Intara et al. (2011) menunjukkan bahwa kadar air tersedia pada tanah yang ditambahkan bahan organik lebih tinggi dibandingkan tanpa bahan organik. Tanah yang terlalu lembap menyebabkan kadar air dalam umbi juga makin banyak, sehingga ketika disimpan terjadi penyusutan bobot yang tinggi. Susut bobot dipengaruhi oleh suhu penyimpanan dan kadar air dalam umbi, makin tinggi suhu ruang penyimpanan dan kadar air dalam umbi maka makin besar pula nilai susut bobot umbi (Mutia et al. 2017).

Tabel 1. Rekapitulasi hasil analisis sidik ragam pengaruh komposisi media tanam tanah, arang sekam, dan pupuk kandang terhadap peubah pertumbuhan bawang merah

\begin{tabular}{|c|c|c|c|c|c|c|c|c|c|}
\hline \multirow{2}{*}{$\begin{array}{c}\text { No. } \\
1 .\end{array}$} & \multicolumn{2}{|c|}{ Parameter amatan } & \multirow{2}{*}{$\frac{F_{\text {hitung }}}{12,16^{* \star}}$} & \multirow{2}{*}{$\begin{array}{c}\text { KK (\%) } \\
6,00\end{array}$} & \multirow{2}{*}{$\begin{array}{c}\text { No. } \\
4 .\end{array}$} & \multicolumn{2}{|l|}{ Parameter amatan } & \multirow{2}{*}{$\frac{\mathbf{F}_{\text {hitung }}}{4,51^{*}}$} & \multirow{2}{*}{$\begin{array}{c}\text { KK (\%) } \\
14,51\end{array}$} \\
\hline & Tingai & $2 \mathrm{MST}$ & & & & \multicolumn{2}{|c|}{ Jumlah umbi per rumpun } & & \\
\hline & Tanaman & $4 \mathrm{MST}$ & $4,53^{*}$ & 8,29 & 5. & \multicolumn{2}{|l|}{ Bobot segar umbi } & $12,51^{* *}$ & 18,17 \\
\hline & & $6 \mathrm{MST}$ & $5,05^{\star}$ & 8,36 & 6. & \multicolumn{2}{|l|}{ Diameter umbi } & $16,32^{\star *}$ & 8,86 \\
\hline \multirow[t]{3}{*}{2.} & Jumlah Daun & $2 \mathrm{MST}$ & $6,36^{* *}$ & 11,84 & 7. & Akumulasi & $1 \mathrm{MSP}$ & $32,30^{\star *}$ & 25,31 \\
\hline & & $4 \mathrm{MST}$ & $5,25^{\star}$ & 16,34 & & bobot & $2 \mathrm{MSP}$ & $41,07^{\star \star}$ & 15,00 \\
\hline & & $6 \mathrm{MST}$ & $6,26^{* *}$ & 15,34 & & & $3 \mathrm{MSP}$ & $25,83^{* *}$ & 15,72 \\
\hline \multirow[t]{3}{*}{3.} & Jumlah & $2 \mathrm{MST}$ & $3,09^{\text {tn }}$ & 18,21 & 8. & \multirow{3}{*}{\multicolumn{2}{|c|}{ Kadar lengas tersedia }} & $11,83^{\star *}$ & 9,75 \\
\hline & anakan & $4 \mathrm{MST}$ & $3,34^{\mathrm{tn}}$ & 23,73 & 9. & & & $21,29^{\star \star}$ & 24,31 \\
\hline & & $6 \mathrm{MST}$ & $5,07^{\star}$ & 20,29 & & & & & \\
\hline
\end{tabular}

Keterangan: $\mathrm{MST}=$ Minggu Setelah Tanam; MSP = Minggu Setelah Panen; ${ }^{*}=$ nyata; ${ }^{* *}=$ sangat nyata; tn $=$ tidak nyata 
Tabel 2. Pengaruh komposisi media tanam tanah, arang sekam, dan pupuk kandang terhadap tinggi, jumlah daun, dan jumlah anakan bawang merah pada umur 2, 4, dan 6 minggu setelah tanam (MST)

\begin{tabular}{llllllllll}
\hline Komposisi & \multicolumn{3}{c}{ Tinggi tanaman $(\mathrm{cm})$} & \multicolumn{3}{c}{ Jumlah daun (helai) } & \multicolumn{3}{c}{ Jumlah anakan (tunas) } \\
\cline { 2 - 9 } media tanam & $2 \mathrm{MST}$ & $4 \mathrm{MST}$ & $6 \mathrm{MST}$ & 2 MST & 4 MST & $6 \mathrm{MST}$ & $2 \mathrm{MST}$ & $4 \mathrm{MST}$ & $6 \mathrm{MST}$ \\
\hline $\mathrm{M} 1=1: 1: 1$ & $16,01 \mathrm{a}$ & $24,66 \mathrm{a}$ & $28,49 \mathrm{a}$ & $6,53 \mathrm{ab}$ & $11,36 \mathrm{ab}$ & $14,75 \mathrm{~b}$ & 1,26 & 1,56 & $1,76 \mathrm{~b}$ \\
$\mathrm{M} 2=2: 1: 1$ & $15,44 \mathrm{ab}$ & $25,22 \mathrm{a}$ & $28,94 \mathrm{a}$ & $7,69 \mathrm{a}$ & $13,19 \mathrm{a}$ & $18,03 \mathrm{a}$ & 1,46 & 2,09 & $2,42 \mathrm{a}$ \\
$\mathrm{M} 3=1: 2: 1$ & $12,91 \mathrm{c}$ & $21,84 \mathrm{~b}$ & $26,03 \mathrm{ab}$ & $5,66 \mathrm{~b}$ & $9,43 \mathrm{~b}$ & $13,13 \mathrm{~b}$ & 1,13 & 1,53 & $1,79 \mathrm{~b}$ \\
$\mathrm{M} 4=1: 1: 2$ & $14,26 \mathrm{~b}$ & $21,71 \mathrm{~b}$ & $24,09 \mathrm{~b}$ & $6,12 \mathrm{~b}$ & $9,39 \mathrm{~b}$ & $12,39 \mathrm{~b}$ & 1,06 & 1,36 & $1,53 \mathrm{~b}$ \\
\hline
\end{tabular}

Keterangan: angka yang diikuti huruf yang sama pada kolom yang sama berarti berbeda tidak nyata berdasarkan uji Jarak Berganda Duncan taraf $5 \%$

Tabel 3. Pengaruh komposisi media tanam tanah, arang sekam, dan pupuk kandang terhadap jumlah, bobot segar, diameter, dan akumulasi susut bobot umbi bawang merah

\begin{tabular}{lcccccc}
\hline \multirow{2}{*}{$\begin{array}{l}\text { Komposisi } \\
\text { media tanam }\end{array}$} & \multirow{2}{*}{$\begin{array}{c}\text { Jumlah umbi / } \\
\text { rumpun }\end{array}$} & \multirow{2}{*}{$\begin{array}{c}\text { Bobot umbi segar } \\
(\mathrm{g})\end{array}$} & $\begin{array}{c}\text { Diameter umbi } \\
(\mathrm{mm})\end{array}$ & \multicolumn{3}{c}{$\begin{array}{c}\text { Akumulasi susut bobot }(\mathrm{g}) \text { pada Minggu } \\
\text { Setelah Penyimpanan (MSP) }\end{array}$} \\
\cline { 6 - 7 } & & & & 1 & 2 & 3 \\
\hline$M_{1}=1: 1: 1$ & $3,56 \mathrm{~b}$ & $10,30 \mathrm{a}$ & $25,66 \mathrm{a}$ & $1,586 \mathrm{c}$ & $3,820 \mathrm{c}$ & $6,178 \mathrm{c}$ \\
$\mathrm{M}_{2}=2: 1: 1$ & $4,33 \mathrm{a}$ & $11,58 \mathrm{a}$ & $26,60 \mathrm{a}$ & $0,954 \mathrm{c}$ & $3,522 \mathrm{c}$ & $6,160 \mathrm{c}$ \\
$\mathrm{M}_{3}=1: 2: 1$ & $3,23 \mathrm{~b}$ & $9,06 \mathrm{a}$ & $22,99 \mathrm{a}$ & $5,078 \mathrm{~b}$ & $8,250 \mathrm{~b}$ & $11,572 \mathrm{~b}$ \\
$\mathrm{M}_{4}=1: 1: 2$ & $3,32 \mathrm{~b}$ & $5,49 \mathrm{~b}$ & $18,24 \mathrm{~b}$ & $14,580 \mathrm{a}$ & $19,682 \mathrm{a}$ & $25,076 \mathrm{a}$ \\
\hline
\end{tabular}

Keterangan: angka yang diikuti huruf yang sama pada kolom yang sama berarti berbeda tidak nyata berdasarkan uji Jarak Berganda Duncan taraf $5 \%$

Akar terpanjang pada media tanam dengan komposisi tanah: arang sekam: pupuk kandang 1:1:2, berbeda sangat nyata dengan perlakuan lainnya (Tabel 4). Arang sekam dan pupuk kandang yang ditambahkan ke media tanam dapat menurunkan bulk density tanah dan menciptakan pori-pori makro yang menyebabkan akar lebih mudah berpenetrasi dan tumbuh memanjang. Hasil penelitian sejalan dengan penelitian Kusuma et al. (Kusuma et al. 2013), yaitu penambahan arang sekam pada proporsi penambahan $50 \%$ menghasilkan akar lateral terpanjang. Pupuk organik mampu menurunkan berat jenis tanah yang menyebabkan tanah menjadi ringan sehingga memberikan kondisi yang baik untuk perkembangan akar dan mempengaruhi pertumbuhan dan hasil (Yahumri et al. 2015). Menurut Agustin et al. (2014), penambahan arang sekam padi meningkatkan ketersediaan pori makro, sehingga akar dapat menembus dan daerah pemanjangan akar semakin luas, sedangkan menurut (Loss et al. 2019) pemberian pupuk kandang menurunkan bulk density tanah, meningkatkan agregasi dan volume pori-pori tanah karena bahan organik memiliki kepadatan partikel yang lebih rendah daripada partikel mineral. Selanjutnya menurut Blok (Blok 2017), pengaruh fisik langsung dari pencampuran partikel organik dan mineral adalah peningkatan ruang pori total, akibat pembentukan agregat tanah yang lebih kompleks. Selain mempengaruhi sifat fisik media tanam, arang sekam juga dapat mendukung pertumbuhan tanaman karena mengandung hara antara lain $\mathrm{C} 77,9 \pm 5,9 \%, \mathrm{H} 3,5 \pm 0,1 \%$, S $0,30 \pm 0,05 \%$, O $18,3 \pm 9,4 \%$ dan memiliki $\mathrm{pH}$ sebesar 8,9 (Theeba et al. 2012).

Kadar lengas tersedia tertinggi diperoleh dari media tanam dengan kombinasi tanah: arang sekam: pupuk kandang=1:1:2, namun berbeda tidak nyata dengan media tanam kombinasi tanah: arang sekam: pupuk kandang $=1: 2: 1$. Salah satu sifat bahan organik adalah mampu mengikat dan menyimpan air, sehingga semakin besar proporsi bahan organik dalam media tanam menyebabkan semakin besar pula air yang tersimpan dalam media tanam tersebut. Sejalan dengan pendapat Hardjowigeno (2015), yaitu bahwa bahan organik merangsang granulasi, meningkatkan kemampuan tanah menahan air, sehingga drainase tidak berlebihan. Terjadi pembentukan agregat tanah yang lebih kompleks ketika partikel organik dikombinasikan dengan partikel mineral sehingga mengakibatkan berat volume rendah, kandungan dan retensi air tinggi serta laju infiltrasi tinggi (Blok 2017).

Tabel 4. Pengaruh komposisi media tanam tanah, arang sekam, dan pupuk kandang terhadap panjang akar bawang merah

\begin{tabular}{lc}
\hline Komposisi media tanam & Panjang akar $(\mathrm{cm})$ \\
\hline$M_{1}=1: 1: 1$ & $12,74 b$ \\
$M_{2}=2: 1: 1$ & $12,24 b$ \\
$M_{3}=1: 2: 1$ & $15,36 a$ \\
$M_{4}=1: 1: 2$ & $10,76 b$ \\
\hline
\end{tabular}

Keterangan: angka yang diikuti huruf yang sama pada kolom yang sama berarti berbeda tidak nyata berdasarkan uji Jarak Berganda Duncan taraf $5 \%$

Tabel 5. Pengaruh komposisi media tanam tanah, arang sekam, dan pupuk kandang terhadap kadar lengas tersedia

\begin{tabular}{lc}
\hline Komposisi media tanam & Kadar lengas tersedia (\%) \\
\hline$M_{1}=1: 1: 1$ & $21,67 \mathrm{c}$ \\
$M_{2}=2: 1: 1$ & $48,65 \mathrm{~b}$ \\
$M_{3}=1: 2: 1$ & $81,87 \mathrm{a}$ \\
$M_{4}=1: 1: 2$ & $83,40 \mathrm{a}$ \\
\hline
\end{tabular}

Keterangan: angka yang diikuti huruf yang sama pada kolom yang sama berarti berbeda tidak nyata berdasarkan uji Jarak Berganda Duncan taraf $5 \%$ 
Kadar lengas yang tinggi pada media tanam berdampak negatif pada hasil tanaman bawang merah. Hal ini terlihat pada parameter bobot segar dan akumulasi susut bobot setelah penyimpanan. Peningkatan proporsi bahan organik dalam media tanam diikuti oleh peningkatan jumlah lengas yang dapat ditahan dalam media tanam tersebut, namun setelah mencapai nilai maksimum kapasitas menahan air menurun seiring meningkatnya jumlah bahan organik. Secara umum, retensi air meningkat seiring dengan peningkatan jumlah bahan organik dalam tanah (Varela et al. 2013). Kadar lengas kapasitas lapangan merupakan jumlah lengas yang ideal untuk menghasilkan pertumbuhan bawang merah yang optimal, sedangkan kadar lengas yang kurang atau lebih dari kapasitas lapangan malah akan menurunkan bobot segar umbi (Anshar et al. 2011).

\section{KESIMPULAN}

Komposisi media tanam berpengaruh nyata terhadap parameter pertumbuhan dan hasil bawang merah. Komposisi tanah: arang sekam: pupuk kandang dengan proporsi 2:1:1 menghasilkan pertumbuhan dan hasil bawang merah terbaik, meskipun berbeda tidak nyata dengan komposisi 1:1:1. Proporsi arang sekam dan pupuk kandang kambing yang lebih banyak dibandingkan tanah mineral dalam media tanam cenderung menurunkan hasil bawang merah.

\section{DAFTAR PUSTAKA}

Agustin AD, Riniarti M, Duryat. 2014. Pemanfaatan limbah serbuk gergaji dan arang sekam padi sebagai media sapih untuk cempaka kuning (Michelia Champaca). J Sylva Lestari. 2(3):49-58. https://dx.doi.org/10.23960/jsl3249-58.

Andalasari TD, Widagdo S, Ramadiana S, Purwati E. 2017. Pengaruh media tanam dan Pupuk Organik Cair (POC) terhadap pertumbuhan dan produksi bawang merah (Allium Ascalonicum L.). In: Prosiding Seminar Nasional Pengembangan Teknologi Pertanian. Prosiding Seminar Nasional Pengembangan Teknologi Pertanian; 7 September 2017; Palembang, ID. Palembang (ID): Politeknik Negeri Lampung. p. 28-34.

Anshar M, Tohari, Sunarminto BH, Sulistyaningsih E. 2011. Pengaruh lengas tanah terhadap pertumbuhan dan hasil tiga varietas lokal bawang merah pada ketinggian tempat berbeda. J Agrol. 18(1):8-14.

Ariska N, Rachmawati D. 2017. Pengaruh ketersediaan air berbeda terhadap pertumbuhan dan hasil tiga kultivar bawang merah (Allium cepa L.). Agrotek Lestari. 4(2):42-50.

Armynah B, Atika, Djafar Z, Piarah WH, Tahir D. 2018. Analysis of chemical and physical properties of biochar from rice husk biomass. J Phys Conf Ser. 979: 012038. https://dx.doi.org/10.1088/1742-6596/979/1/012038.

Blok C. 2017. Compost for soil application and compost for growing media. In: Van der Wurff AWG, Fuchs, JG, Raviv M, Termorshuizen AJ, editors. Handbook for composting and compost use in organic horticulture. (NL): BioGreenhouse . p. 89-98.
Center for Agriculture Food and the Environment. 2020. Checklist: Effects of growing media characteristics on water and nutrient management. Massachusetts (US): Umass Extension. pp. 34-39.

Dewi MK, Sutrisna IK. 2016. Pengaruh tingkat produksi, harga dan konsumsi terhadap impor bawang merah di Indonesia. E-Jurnal Ekon Pembang Univ Udayana. 5(1):139-149.

Ghorbani M, Asadi H, Abrishamkesh S. 2019. Effects of rice husk biochar on selected soil properties and nitrate leaching in loamy sand and clay soil. Int Soil Water Conserv Res. 7(3):258-265. https://dx.doi.org/10.1016/j.iswcr.2019.05.005.

Hardjowigeno S. 2015. Ilmu Tanah. 8th ed. Jakarta (ID): Akademika Pressindo. 288 p.

Hartatik W, Widowati LR. 2006. Pupuk kandang. In: Simanungkalit RD, Suriadikarta DA, Saraswati $R$, Setyorini D, Hartatik W, editors. Pupuk organik dan pupuk hayati. Jakarta (ID): Balai Besar Penelitian dan Pengembangan Sumberdaya Lahan Pertanian, Badan Penelitian dan Pengembangan Pertanian. p. 59-82.

Intara YI, Sapei A, Sembiring N, Djoefrie MHB. 2011. Pengaruh pemberian bahan organik pada tanah liat dan lempung berliat terhadap kemampuan mengikat air. J Ilmu Pertan Indones. 16(2):130-135.

Juniyati T, Adam A, Patang P. 2016. Pengaruh komposisi media tanam organik arang sekam dan pupuk padat kotoran sapi dengan tanah timbunan terhadap pertumbuhan dan kelangsungan hidup tanaman kangkung darat (Ipomea reptans Poir). J Pendidik Teknol Pertan. 2(1):9-15. https://dx.doi.org/10.26858/jptp.v2i1.5149.

Kantikowati E, Karya, Yusdian Y, Suryani C. 2019. Chicken manure and biofertilizer for increasing growth and yield of potato (Solanum tuberosum I.) of Granola varieties. IOP Conf Ser Earth Environ Sci. 393:012017. https://dx.doi.org/10.1088/1755-1315/393/1/012017.

Khater ESG. 2015. Some physical and chemical properties of compost. Int J Waste Resour. 05(1): 000172.

Khokhar KM. 2017. Environmental and genotypic effects on bulb development in onion - a review. J Hortic Sci Biotechnol. 92(5):448-454. https://dx.doi.org/10.1080/14620316.2017.1314199.

Kolo A, Raharjo KTP. 2016. Pengaruh pemberian arang sekam padi dan frekuensi penyiraman terhadap pertumbuhan dan hasil tanaman tomat (Lycopercicom esculentum Mill). Savana Cendana. 1(03):102-104.

https://dx.doi.org/10.32938/sc.v1i03.54.

Kurnianingsih A, Susilawati, Sefrila M. 2019. Karakter pertumbuhan tanaman bawang merah pada berbagai komposisi media tanam. J Hortik Indones. 9(3):167173. https://dx.doi.org/10.29244/jhi.9.3.167-173.

Kusuma AH, Izzati M, Saptiningsih E. 2013. Pengaruh penambahan arang dan abu sekam dengan proporsi yang berbeda terhadap permeabilitas dan porositas tanah liat serta pertumbuhan kacang hijau (Vigna radiata L.). Bul Anat Fisiol. 21(1):1-9. 
Landis TD, Jacobs DF, Wilkinson KM, Luna T. 2014. Growing media. In: Wilkinson KM, Landis TD, Haase DL, Daley BF, Dumroese RK, editors. Tropical nursery manual a guide to starting and operating a nursery for native and traditional plants. Washington (DC): United States Department of Agriculture. p. 101-122.

Loss A, Couto R, Brunetto $G$, da Veiga $M$, Toselli $M$, Baldi E. 2019. Animal manure as fertilizer: changes in soil attributes, productivity and food composition. Int J Res -GRANTHAALAYAH. 7(9):307-331. https://dx.doi.org/10.29121/granthaalayah.v7.i9.2019.615.

Lumbanraja P, Harahap EM. 2015. Enhancing soil water holding capacity and cation exchange capacity of sandy soil with application of manure on simalingkar soil. J Pertan Trop. 2(1):74-88. https://dx.doi.org/10.32734/jpt.v2i1.2881.

Manurung M. 2019. Konsumsi dan neraca penyediaan penggunaan bawang merah. In: Sumantri A, editor. Buletin konsumsi pangan, Volume 10 Nomor 12019. Jakarta (ID): Pusat Data dan Sistem Informasi Pertanian Sekretariat Jenderal Kementerian Pertanian. pp. 56-62.

Mutia AK, Purwanto YA, Pujantoro L. 2017. Perubahan kualitas bawang merah (Allium Ascalonicum L.) selama penyimpanan pada tingkat kadar air dan suhu yang berbeda. J Penelit Pascapanen Pertan. 11(2):108. https://dx.doi.org/10.21082/jpasca.v11n2.2014.108-115.

Ramli, Paloloang AK, Rajamuddin UA. 2016. Perubahan sifat fisik tanah akibat pemberian pupuk kandang dan mulsa pada pertanaman terung ungu (Solanum Melongena L.), entisol, Tondo Palu. E-J Agrotekbis. 4(2):160-167.

Sudarma IK, Proklamita TL. 2012. Pertumbuhan dan hasil beberapa kultivar bawang merah pada berbagai durasi genangan. PARTNER. 22(2):474-486. https://dx.doi.org/10.35726/jp.v22i2.242.

Sunaryo Y, Purnomo D, Darini MT, Cahyani VR. 2018. Nutrients content and quality of liquid fertilizer made from goat manure. J Phys Conf Ser. 1022:012053. https://dx.doi.org/10.1088/1742-6596/1022/1/012053.

Surya JA, Nuraini Y, Widianto. 2017. Kajian porositas tanah pada pemberian beberapa jenis bahan organik di perkebunan kopi robusta. J Tanah Sumberd Lahan. 4(1):463-471.
Syahputra E, Rahmawati M, Imran S. 2014. Pengaruh komposisi media tanam dan konsentrasi pupuk daun terhadap pertumbuhan dan hasil tanaman selada (Lactuca sativa L.). J Floratek. 9(1):39-45.

Syawal Y, Susilawati, Ghinola E. 2019. Pengaruh komposisi media tanam terhadap pertumbuhan dan hasil tanaman bawang merah (Allium cepa L. Var Bima). Maj IIm Sriwij. 31(2019):1-7.

Theeba M, Bachmann RT, Illani ZI, Zulkefli M, Husni MHA, Samsuri AW. 2012. Characterization of local mill rice husk charcoal and its effect on compost properties. Malays J Soil Sci. 16(1):89-102.

Tsai CC, Chang YF. 2020. Effects of rice husk biochar on carbon release and nutrient availability in three cultivation age of greenhouse soils. Agronomy. $10(7): 990$.

https://dx.doi.org/10.3390/agronomy10070990.

Umami A, Darmanti S, Haryanti S. 2011. Pertumbuhan dan produktivitas tanaman bawang merah (Allium ascalonicum L. var. Tiron) dengan perlakuan Gracilaria verrucosa sebagai penjerap air pada tanah pasir. Bioma Berk IIm Biol. 13(2):60-66.

Varela OM, Rivera EB, Huang WJ, Chien CC, Wang YM. 2013. Agronomic properties and characterization of rice husk and wood biochars and their effect on the growth of water spinach in a field test. J Soil Sci Plant Nutr. 13(2):251-266. https://dx.doi.org/10.4067/S0718-95162013005000022.

Vengadaramana A, Jashothan PT. 2012. Effect of organic fertilizers on the water holding capacity of soil in different terrains of Jaffna peninsula in Sri Lanka. J Nat Prod Plant Resour. 2(4):500-503.

Yahumri, Yartiwi, Siagian IC, Rahman T. 2015. Growth response and production of onion by applying organic fertilizer from industrial waste and animal waste. In: Promoting local resources for food and health. ISEPROLOCAL; 12-13 Oktober 2015; Bengkulu, ID. Bengkulu (ID): Fakultas Pertanian, Universitas Bengkulu. p. 468-472.

Zulkarnain M, Prasetya B, Soemarno. 2013. Pengaruh kompos, pupuk kandang, dan custom-bio terhadap sifat tanah, pertumbuhan dan hasil tebu (Saccharum officinarum L.) pada entisol di kebun Ngrakah-Pawon, Kediri. Indones Green Technol J. 2(1):45-52. 